\title{
Additional select bibliography
}

\section{MANUSCRIPTS}

\section{Balliol College Library, Oxford}

MSS 455(7), Medical recipes copied by Nicholas Crouch, seventeenth century.

\section{Bodleian Library, Oxford}

Alm. 78(2)-(3), diaries in Lilly's almanacs, I647-48.

Ashm. 72(2), diary in Allestree's almanac, I643.

— $72(7)$, diary in Booker's almanac, 1645 .

— 247 (I9), diary in Vaux's almanac, I655.

—, $605(\mathrm{I})$, diary in Lilly's almanac, I67I.

MS Radcliffe Trust, e3o, The gouernayle of helthe (late fifteenth century).

Rawl. Alm. 5(I), diary in Allestree's almanac, I643.

—, Alm. 5(I4), diary in Pond's almanac, I64I.

Alm. 78(2)-(3), diaries in Lilly's almanacs, $1647-48$.

Wood. Alm. B(6), diary in Gallen's almanac, I683.

—, Alm. F(8), diary in D. Partridge's almanac, $\mathrm{I} 694$.

\section{British Library}

Add. MS 4293, ff. III-I26, I28, Correspondence between William Lilly and the Ashmoles I670-77.

Add. MS 4403, ff. II3-II9b, Pell Papers, Diary in Samuel Morland's almanac, I650.

Add. MS 4956, William Courten (al. Charleton), Diary in Saunders' almanac, 1698.

Add. MS I8,72I, Sir Robert Markham, Bart. of Sedgebroke, Diary in Gadbury's almanac, I68I.

Add. MS 22,550, Henry Hyde, Second Earl of Clarendon, Diary in Goldsmith's almanac, I69I.

Add. MS 34,I70, Isabella, wife of Sir Roger Twysden, Second Bart., Diary, I647-49, I65I.

Add. MS 4I,202, Sir Edward Nicholas, Memoranda Books in Gallen's almanacs I649-69; and Sir John Nicholas, Memoranda Books in Gallen's almanac, I667-I703.

Add. MS 54333, Oxenden Manuscripts, II, Henry Oxenden, Diary in Booker's almanac, I646.

Sloane 2279-80, ff. I-36, Astrological and mathematical collections belonging to Henry Coley $1665-95$. 


\section{Buckinghamshire Records Office}

Chequer's Mss: D/138/16/I, Commonplace book of Henry Croke, I659.

—, D/138/16/2, Receipt Book, I654.

—, D/138/16/3, Household Book, 1676.

D/138/16/16/I, Book of Receipts, seventeenth century.

D/W/97/7, Pocket Book of Roger Hill, I640-42.

D/X 58I/2, John King of Steeple Claydon, Diary in Rider's British Merlin, I687.

D/X 775, Diary in copy of Rider's British Merlin, I667.

\section{Folger Shakespeare Library, Washington DC}

MS.A2254, ff. 25-27 and 36r-v, Sarah Sales, Diary in Rider's British Merlin, I680.

\section{Guildhall Library, London}

MS 2890 Blacksmith's Company book of by-laws (early sixteenth century).

MS 5526 Farriers' Company Apprentice Book (c.I620-I743).

MS 5534-4 Farrier Court Journals (I674-I867).

\section{Newberry Library, Chicago}

Alm.g.I670.I, Diary [in Rider's almanac] I670.

\section{New York Academy of Medicine}

RBS.2I.B, Collection of recipes, I7I9.

\section{Stationers' Company}

Journal Book, f. 2I and f. I57, I694.

\section{Suffolk Records Office}

Parish Registers of Sudbury All Saints 1564-1808, Bury St Edmunds Record Office.

\section{PRINTED PRIMARY SOURCES}

Agrippa, Henry Cornelius, The Vanity of Arts and Sciences (London, 1694).

Allen, Charles, Curious Observations in that difficult part of Chirurgery, Relating to the Teeth (Dublin, I687).

Allestree, Richard, The Gentlemans [sic] Calling (London, I660).

—, A Sermon Preached before the King at White-Hall (London, I663).

- The Government of the Tongue (London, I675).

- The Art of Contentment (London, I682).

- The Ladies [sic] Calling (Oxford, $6^{\text {th }}$ impression, I693).

Almond, Robert, The English Horsman and Complete Farrier (London, I673).

Ambrose, Paré, The Workes (London, I634). 


\section{Additional select bibliography}

Ames, Richard, A Farther Search after Claret (London, I634).

—, An Elegy On the Death of Dr. Thomas Saffold (London, I691).

Andrews, William, The Astrological Physitian (London, 1656).

Anon., A booke of soueraigne appoued [sic] medicines and remedies (London, I577).

- The Englishman's Docter, or the Schole of Salerne (London, I607).

—, The English Farrier, or, Countrey-mans [sic] Treasure (London, I63I).

- News out of the West, or the Character of a Mountebank (London, I637).

—, An Act against Unlicensed and Scandalous Books and Pamphlets (London, 1639).

_- To all printers, booke-sellers, booke-binders, free-men of the Company of Stationers (London, I645).

- Excellency of Physick and Chirurgie (London, 1652).

—., A Brief discourse concerning printing and printers (London, I663).

—, Food and Physick for every Householder, Q his Family, During the Time of Plague (London, I665).

- Famous and Effectual Medicine to Cure the Plague (London, I670).

- The Character of a Coffeehouse with the symptoms of a town-wit (London, 1673 ).

—. News from the Press: or, the Black Devil Conjured (London, I673).

- The Gentleman's Jockey, and Approved Farrier (London, I676).

—, An Elegy Upon the Death of Mr. William Lilly, the Astrologer (London, I68I).

—, A Help to Discourse, or, More merriment mixt with Serious Matter (London, I682).

- An ordinance ordained, devised, and made by the Master, and Keepers or Wardens and commonality of the mystery or art of Stationers of the City of London (London, I683).

- - A Catalogue of the Libraries of Two Eminent Persons (London, I684).

—, The Experienced Jockey, Compleat Horseman, or Gentlemans [sic] Delight (London, I684).

—, A Catalogue of the Library of Choice Books Latin and English of the Reverend and Learned Dr. Richard Lee (London, I685).

Artherton, Henry, The Christian Physician (London, I683).

A.S., The Gentleman's Compleat Jockey: with the Perfect Horseman and Experience'd Farrier (London, I697).

Askham, Anthony, A little herbal of the properties of Herbes (London, 1562 ).

Athenian Mercury, The (No. I4, 2I July I694).

Atwell, G., An apology, or, Defence of the divine art of natural astrologie (London, I660).

Axford, J., Philosophical and astrological rare secrets brought to light for the good of mankind (London, I693).

Ball, William, A Briefe Treatise concerning the Regulating of Printing (London, I651).

Barret, Robert, The Perfect and Experienced Farrier (London, I660).

Barrough, Philip, The Method of Physick (London, I652).

Bartholomaeus, Anglicus, Batman uppon Bartholome, his booke De Proprietabus reum, trans.

Stephen Batman (London, I582). 
Baxter, Richard, The Poor Man's Family Book (London, I674).

Berlu, Joseph Jacob, The Treasury of Drugs Unlock'd or A Full and True Description of all sorts of Drugs, and Chymical Preparations, sold by Druggists (London, I690).

Blagrave, Joseph, The Epitome of the Art of Husbandry (London, I670).

—. Blagrave's Astrological Practice of Physick (London, I672).

—., Blagrave's supplement or enlargement to Mr. Nich Culpeppers English Physitian (London, I674).

—, Blagrave's Introduction to Astrology (London, I682).

Blancard, Stephen, The Physical Dictionary (London, I693).

Bolnest, Edward, Medicina instaurata, or, A brief account of the true grounds and principles of the art of physick (London, I665).

Boorde, Andrew, The pryncples of astronmaye the whiche diligently persrutyd is in maners pronosticacyon to the worldes end (London, I547).

- The bruiarie of health (London, I575).

—- A Compendious Regiment, or Dietarie of Health (London, I576).

Boyle, Robert, Medicinal Experiments: Or, A Collection of Choice and Safe Remedies (London, I696).

Bradwell, Stephen, Physick for the Sicknesse Called the Plague (London, I636).

Brassley, Anthony Lambert and Philip Saunders, Accounts of the Reverend John Crankanthorp of Fowlmere 1682-1710 (Cambridge, UK, I988).

Bromfield, M., A brief discovery of the chief causes, signs and effects of that most reigning disease, the scurvy (London, I679).

Bullard, John, A catalogue of extraordinary Greek and Latin books, published by Stephes, Aldus and other curious authors. Also a choice collection of medicinal and chymical books, being the library of Dr. Andrew Clench (London, I692).

—, A catalogue of theological, philosophical, historical, philological, medicinal a chymical books in the Greek, Latin, Italian, German and English languages . . of Dr. Rugely (London, I697).

Bullein, William, A new Boke of Physicke (London, 1559).

Bunyan, John, A book for boys and girls (London, I686).

Burton, Robert, The Anatomy of Melancholy (London, I62I).

C.H., B.C. and C.M. (Ingenious Artists), The Perfect Husbandman, or The Art of Husbandry (London, I657).

Chamberlayne, John, The Natural history of coffee, thee, chocolate, tobacco in four sections (London, I682).

Charleton, Walter, Natural history of the passions (London, I674).

Charnock, Stephen, A discourse of divine providence (London, I684).

Childrey, Joshua, Indago astrologica: or, a brief and modest enquiry into some principal points of astrology (London, I652).

Claridge, John, The Shepheard's Legacy (London, I670).

Clifford, Christopher, The schoole of horsemanship (London, I585). 


\section{Additional select bibliography}

Cocke, William, Hygiene, or, A Plain and Practical Discourse Upon the First of the Six NonNaturals (London, I665).

—, Meteorologia, or, The true way of foreseeing and judging the inclination of the air and alteration of the weather (London, I67I).

—, Kitchin-Physick: or, Advice to the Poor, BY Way of Dialogue (London, I676).

Cocker, Edward, The Compleat Writing Master (London, I670).

Coelson, The poor-mans [sic] physician and chyurgion (London, I656).

—, Lancelot, Philosophia Maturata: an Exact Piece of Philosophy (London, I668).

Cogan, Thomas, The Haven of Health (London, I6I2).

Colbatch, John, Novum Lumen Chirurgicum, or a New Light of Chirurgery (London, I685).

- Four Treatises of Physick and Chirurgery (London, I698).

Coles, William, The Art of Simpling (London, I657).

Coley, Henry, Clavis Astrologiae Elimata: or A Key to the Whole World of Astrologie (London, I669).

College of Physicians, Certain Directions for the Plague (London, ${ }_{16} 66$ ).

Collop, John, On Noah Big's vanity of the Craft of Physick (London, ${ }_{6}{ }_{5} 6$ ).

- Poesis Rediviva (London, $\mathrm{I}_{5} 6$ ).

Company of Stationers, A Transcript of the Registers of the Worshipful Company of Stationers, from 1640-1708 A.D., Vols I-3 (London, I9I4).

- , and William Jackson (ed.) Records of the Court of the Stationers' Company (London, I957).

Cotta, John, A Short Discoverie of the Unobserved Dangers of Severall Sorts of Ignorant and Inconsiderate Practitioners of Physick (London, I6I2).

Cox, Nicholas, The gentleman's recreation: in four parts (London, 1674 ).

Crawshey, John, The Countrymans [sic] Instructor (London, I636).

Crowshey, John, The Good-husbands [sic] Jewel (York, r66I).

Culpeper, Nicholas, Opus Astrologicum (London, I645).

—, A Physical Directory: or a Translation of the Dispensatory made by the College of Physicians of London (London, I649).

—, Semeiotica Uranica, or an Astrological Judgment of Disease (London, I651).

- Catastrophe Magnatum: or, The Fall of Monarchie (London, I652).

- The English Physitian, or an Astrolog-Physical [sic] Discussion of the Vulgar Herbs of this Nation (London, I652).

—. Complete Herbal and English Physician Enlarged (London, I653; reprint Ware, I995).

—, Pharmacopoeia Londinensis: or the London Dispensatory (London, I653).

- New Method of Physick (London, I654).

- The Expert Doctor Dispensatory (London, 1657$)$.

—, Galen's Art of Physick (London, I657).

—., Astrological Judgement of Diseases (London, I665). 
—, Medicaments for the Poor or Physick for the Common People (London, I670).

—., Anima Astrologiae: or, a Guide for Astrologers (London, I676).

- Culpeper's School of Physick (London, I678).

Daffy, Anthony, Elixir Salutis: The Choise Drink of Health, or Health-bringing Drink (London, I674).

Dariot, Claude, A briefe and most easie introduction to the astrologicall judgment of the starres (London, I598).

Dawson, Thomas, A Book of Cookery, and the Order of Meates to be Served to the Table (London, I650).

De Grey, Thomas, The Compleat Horse-man and Expert Ferrier (London, I651).

De la Charriere, Joseph, A Treatise of the Operations of Surgery (London, I7I2).

De Mediolano, Joannes, The Englishmans docter, or, The schoole of Salerne (London, I607).

Digbie, K., The Closet of the Eminently Learned Sir Kenelme Digbie Knight Opened (London, I669).

Digges, Leonard, A prognostication euerlasting of right good effect (London, 1592).

Dixon, Roger, Consultum Sanitatis, A Directory to Health, Displayed in Several Choice Medicines (London, I663).

Dubrauius, Ianus, A new book of good husbandry (London, 1599).

Dunton, J., A Voyage Round the World (London, I691).

—, The Life and Errors of John Dunton (London, I705).

Edlyn, R., Observations Astrologicae or an Astrological Discourse (London, I659).

Eland, William, A Tutor to Astrology: Or, Astrology made easie (London, I657).

Elkes, Richard, Approved Medicines of Little Cost, to Preserve Health and Also to Cure Those That are Sick (London, $\mathrm{I}_{52}$ ).

Elyot, Thomas, The Castel of helth (London, I539).

E.M., Inquiries into the General Catalogue of Diseases Shewing The Errors and Contradictions of that Establishment (London, I69I).

E.R., The Experienced Farrier, or, Farring Completed (London, I678).

Everard, Giles, Panacea: or, The Universal Medicine, Being a Discovery of the Wonderful Vertues of Tobacco (London, I659).

Fitzherbert, John, The Boke of Husbandry (London, I573).

Fletcher, Richard, The Character of a True Physician (London, I676).

Fontanus, Nicholas, The Womans [sic] Doctor (London, 1652)

Gadbury, John, Philastrogus Knavery Epitomized (London, I652).

—, Animal Cornatum; or, . . . A brief method of the grounds of Astrology (London, I654).

- Genethlialogia, or The Doctorine of Nativities, and the Doctrine of Horary Questions, Astrologically Handled (London, I658).

- The Nativity of the Late King Charles Astrologically and Faithfully Performed (London, 1659).

—, Nuncius Astrologicus (London, I659). 


\section{Additional select bibliography}

Gadbury, John, Natura Prodigiorum: or, A Discourse Touching the Nature of Prodigies (London, I660).

—, Britain's Royal Star (London, I66I).

— Dies Novissimus: or, Dooms-Day Not so Near as Dreaded (London, I664).

—, London's Deliverance Predicted (London, I665).

—, A Brief Relation of the Life and Death of . . Mr. Vincent Wing (London, I669).

- Thesaurus Astrologiae (London, I674).

—, Astrological Predictions for the Year 1679 (London, I679).

—, Magna Veritas: or, John Gadbury (Student in Physick and Astrology) not a Papist but a True Protestant (London, I680).

- The Works of That Late Most Excellent Philosopher and Astronomer Sir George Wharton Bart (London, I683).

Gale, Thomas, Certaine workes of chirurgerie (London, $\mathrm{I}_{5} 63$ ).

Gardiner, Edmund, Phisiciall and approved Medicines (London, I6II).

Garencieres, T., A Mite Cast into the Treasury of the Famous City of London (London, I665).

Gayton, Edmund, The Art of Longevity, or, A Dieticall Institution (London, I659).

G.C., A Briefe and Most Easie Introduction to the Astrologicall Judgement of the Starres (London, I598).

Gell, Robert, Stella Nova, A New Starre Leading Wisemen unto Christ (London, I649).

—, A Sermon Touching Gods Government of the World by Angels (London, I650).

- The New Jerusalem (London, I652).

Gerard, John, The herbal or Generall historie of plants (London, I597).

—, The herbal or Generall historie of plants, ed. T. Johnson (London, I633).

Geree, John, Astrologo-Mastix, or a Discovery of the Vanity and Inquiry of Judiciall Astrology (London, I646).

Gesnder, Konrad, The practise of the new and old phisicke (London, I599).

Gildon, Charles, The Post-boy rob'd of his Mail (London, I692).

Girolamo, Cardano, Cardanus comforte translated into Englishe, trans. T. Churchyarde (London, I573).

Goad, John, Astro-meteorologica, or, Aphorisms and Discourses of the Bodies Coelestial (London, I686).

Goddard, Jonathan, A Discourse Setting for the Unhappy Condition of the Practice of Physick in London (London, I680).

Godfridus, The Knowledge of Thinges Unknowne (London, 1585).

Godson, Robert, Astrologia Reformata: A Reformation of the Prognostical Part of Astronomy, Vulgarly Termed Astrology (London, I697).

Goeurot, Jean, The kegiment [sic] of life (London, 1546).

Graunt, John, Natural and Political Observations Mentioned in a Following Index and Made Upon the Bills of Mortality (London, I662). 
Grymes, Thomas, The Honest and Plaine-dealing Farrier or a Present Remedy for Curing Diseases and Hurts in Horses (London, I636).

Hakewill, George, An apologie of the power and providence of God in the government of the world (London, I627).

Hart, James, Klinike, or, The Diet of the Diseased (London, I633).

Harvey, Gideon, The Family-Physician and the House-Apothecary (London, I678).

- The Conclave of Physicians (London, 1683).

- The Art of Curing Diseases by Expectations (London, I689).

Harward, Michael, The Herds-man's Mate: Or, a Guide for Herds-men (Dublin, I673).

Heydon, Christopher, An astrological discourse (London, I690).

Hopton, Arthur, Speculum topographicum: or, The topographicall glasse (London, I6II).

Howell, James, Londonopolis, an historicall discourse or perlustration of the city of London (London, 1657).

J.B., gent., A Faire in Spittle Fields, Where All the Knick Knacks of Astrology Are Exposed to Open Sale (London, I652).

J.B., gent., The Epitome of the Art of Husbandry (London, I670).

Jeake, Samuel, An Astrological Diary of the Seventeenth Century, eds Michael Hunter and Annabel Gregory (Oxford, I988).

_- A Radical's Books, The Library Catalogue of Samuel Jeake of Rye, 1623-90, eds Michael Hunter, Giles Mandelbrote, Richard Ovenden and Nigel Smith (Cambridge, UK, 1999).

J.H., Astronomia Crystallina: or, A New and Clear Way to know and behold all the Heavenly Motions (London, I670).

Josselin, R., The Diary of Ralph Josselin 1616-1683, ed. Alan Macfarlane (London, I976).

Knight, William, Vox stellarum: or, the voyce of the stars (London, I68I).

Ladies [sic] Mercury, The (No. I, 28 February I693).

Lambert, J., The Countrymans [sic] Treasure (London, I676).

Langton, Christopher, A uery brefe treatise, orderly declaring the pri[n]cipal parts of phisick (London, I547).

LeClerc, Daniel, The Compleat Surgeon (London, I70I).

- The History of Physick, or an Account of the Rise and Progress of the Art, trans. Dr Drake and Dr Baden (London, I699).

—, A Natural and Medicinal History of Worms Bred in the Bodies of Men and Other Animals, trans. J. Browne (London, I72I).

Leminus, Levinus, The Secret Miracles of Nature (London, I658).

—, A Discourse Touching Generation (London, I664).

Lessius, Leonard, Hygiasticon: or, the right course of preserving Life and Health unto extream old age (Cambridge, UK, I634).

Lilly, William, A Prophecy of the White King and Dreadfull Dead-man Explained (London, I644).

- The Starry Messenger, or, an Interpretation of that Strange Apparition of Three Suns (London, I645). 


\section{Additional select bibliography}

Lilly, William, Christian Astrology (London, I647).

- Astrologicall Predictions of the Occurrences in England (London, I648).

—-, Monarchy or No Monarchy in England (London, I651).

- - Annus Tenebrosus (London, I652).

— - The Last of the Astrologers: Mr William Lilly's History of his Life and Times, ed. K.M. Briggs (London, I7I5; reprinted I974).

Lockyer, Lionel, An advertisement, concerning those most excellent pills called Pilulae radiis solis extractae (London, 1664).

Lovell, William, The Dukes [sic] desk newly broken up: Wherein is discovered Divers Rare Recipts [sic] of Physick and Surgery (London, I66r).

L.P., The Astrologer's Bugg-beare (London, I652).

Lydgate, John, The gouernayle of helthe (London, I490).

Makluire, John, The Buckler of bodilie health whereby health may bee defended, and sickesse repelled (Edinburgh, $\mathrm{I}_{3} \mathrm{O}$ ).

Markham, Gervase, Cavelrice, Or The English Horseman: Contayning all the Arte of Horsemanship (London, I607).

—, Countrey Contentments, Book 2: The English Huswife (London, I6I5).

—, The English Housewife, ed. Michael Best (London, I6I5, reprint London, I994).

- Cheape and Good Husbandry (London, 1616$)$.

- Markham's Faithfull Farrier (London, I638).

—, A Way to Get Wealth (London, I66r).

—, Markham's Master-piece Revived (London, I68I).

Mascal, Leonard, The Government of Cattel (London, I662).

Massaria, Alessandro, De Morbis Foemineis, the Womans [sic] Counsellour, trans. R.T. (London, I657).

Matthews, Richard, The Unlearned Alchymist His Antidote (London, I662).

Mayrnwaringe, Edward, Vita sana \& longa: the preservation of health and prolongation of life (London, I669).

Meager, Leonard, The mystery of husbandry, or, arable, pasture and woodland improved (London, I697).

Melton, John, Astrologaster, or, The figure-caster (London, I620).

Merrett, Christopher, The Accomplisht Physician (London, I670).

- Self-Conviction; or an Enumeration of the Absurdities, Railings, Q 2 c. Against the College, and Physicians in General (London, I670).

Montulmo, Antonius De, A right excellent treatise of Astronomie (London, I554/1555).

Moore, Philip, The hope of health (London, 1565 ).

Moxon, Joseph, A Tutor to Astronomy and Geography (London, I665).

N.P., The Vertue and Operation of this Balsame (London, I6I5).

Nendick, Humphrey, A Book of Directions and Cures Done by that Safe and Successful Medicine called Nendick's Pills (London, c.I677). 
Newcastle, Marchioness, Philosophical and Physical Opinions (London, I663).

Nostradamus, Michael, An excellent treatise shewing what perilous and contagious infirmities shall insue, trans. L. Philotis (London, 1569 ).

Oglander, John, A Royalist's Notebook: The Commonplace Book of Sir John Oglander Kt. of Nunwell (London, I936).

Osborn, Dorothy, Letters from Dorothy Osborne to Sir William Temple 1652-1654, ed. Edward Abbott Parry (London, 1903).

Oxiden, The Oxinden Letters 1607-1642, ed. Dorothy Gardiner (London, I933).

Packe, Christopher, The Works of the Highly Experienced and Famous Chymist, John Rudolph Glauber (London, I689).

Palmer, Thomas, The Admirable Secrets of Physick and Chyrurgery (London, I696).

Paré, A., The Workes (London, I634).

Parkinson, John, Theatrum Botanicum: the Theatre of Plants or, an Herball of Large Extent (London, 1640 ).

Partridge, John, The Widdowes Treasure Plentifully Furnished with Sundry secrets: and Approved Secrets in Physicke and Chirurgy (London, I63I).

- Mene tekel: Being an Astrological Judgment on the Great and Wonderful Year 1688 (London, I689).

—- Remarkable Predictions of that Great Prophet Michael Nostradomus [sic] (London, I689).

- The Treasurie of Commodious Conceits: and Hidden Secrets (London, I69I).

—, Opus Reformatum: or, A Treatise of Astrology (London, I693).

- Defectio Geniturarum: Being an Essay toward the Reviving and Proving the True Old Principles of Astrology (London, I697).

Paynell, Thomas, Regimen sanitatis Salernitum (London, I539).

Peacham, Henry, The Complete Gentleman: The Truth of our Times, and The Art of Living in London (London, I622; reprint Ithaca, New York, 1962).

Pechey, J., A General treatise of the diseases of maids, bigbellied women, child-bed women and widows (London, 1696 ).

—, A Plain Introduction to the Art of Physick (London, I697).

- The Compleat Midwife's Practice Enlarged (London, I698).

Pepys, Samuel, The Diary of Samuel Pepys, eds Robert Latham and William Matthews (London, I970-83: II vols).

Physiologus, Philotheos, The Good Housewife made a Doctor (London, n.d.).

[Platter, Felix], [the author is given as 'Anon., but Platter generally accepted to be the author of this work] Delights for Ladies, To adorn their Persons, Tables, Closets and Distillatories (London, I654).

Platter, Felix, Nicholas Culpeper and Abidiah Cole, Platerus Histories and Observations Upon most Diseases offending the Body and Mind (London, I664).

Poole, John, Country Astrology in Three Books (London, I650).

Poole, William, The Country Farrier (London, I652).

Ptolemy, The compost of Ptholomeus, prince of astronomye (London, I552). 


\section{Additional select bibliography}

Ramsey, William, Lux Veritatis, or Christian Judicial Astrology Vindicated (London, I650).

—, Vox Stellarum (London, I652).

—, Astrologica Restaurata (London, I653).

Raunce, John, Astrologia Accusata Pariter or the Diabolical Art of Judical Astrologie (London, I650).

R.B., The Excellencie of Physick and Chirurgerie (London, 1652).

Riolanus, Johannes, A Sure Guide: or The Best and Nearest Way to Physick and Chirurgery, trans. Nicholas Culpeper (London, I67I).

Riverius, Lazarus, Nicholas Culpeper and Abidiah Cole, The Practice of Physick (London, I66I).

Rondelet, William, The Countrey-mans [sic] apothecary (London, I649).

Ross, Alexander, Arcana Microcosmi, or, The hid Secrets of Man's Body discovered (London, I652).

Rowze, R., The Queens [sic] Wells (London, I632).

Rumsey, Walter, Organon salutis. Or an instrument to cleanse the stomach (London, I659).

Sadler, John, The Sick Womans [sic] Private Looking-glass (London, I636).

Sala, A., Opiologia, or, A treatise concerning the nature, properties, true preparation and safe use and administration of opium, trans. T. Bretnor (London, I6I8).

Salmon, William, Synopsis medicinae, or, a Compendium of astrological Galenical, \& chymical physick philosophically deduced from the principles of Hermes and Hippocrates (London, I67I).

- Pharmacopoeia Londinensis: Or, the New London Dispensatory (London, I678).

—, Parateremata or, Select Physical and Chyrurgical Observations (London, I687).

—, Medicina Practica: or, Practical Physick (London, I692).

—, A Rebuke to the Authors of the Blew-Book: call'd The State of Physick in London (London, I698).

—, The Family Dictionary: or Household Companion (London, I705).

- Collectanea Medica (London, I703).

Saunders, Richard, Palmistry, the secrets thereof disclosed (London, $\mathrm{I}_{33}$ ).

- The Astrological Judgement and Practice of Physick (London, I677).

Seal, James, England's timely warning-piece, or, The wonderfull prophecies of Bishop Usher (London, I682).

Sermon, William, An advertisement (London, I669).

—. The Ladies [sic] Companion, or the English Midwife (London, I67I).

Shirley, John, The Accomplished Ladies [sic] Rich Closet of Rarities (London, I69I).

Smith, John, A Compleat Practice of Physick (London, $\mathrm{I}_{5} 6$ ).

Snape, Andrew, The anatomy of an horse (London, I683).

Solleysel, S., The Parfait Mareschal or Compleat Farrier, trans. Sir W. Hope (Edinburgh, I696).

Spire, John, The natures, uses, \& doses of several approved and experienced medicines (London, I698). 
Stationers' Company, To the Honourable House of Commons assembled in Parliament: an abstract of the generall grievances of the poor free-men and journey printers oppressed (London, I62I).

Stevens, Charles and John Liebault, Maison Rustique, Or, The Countrey Farme, trans. Richard Surflet (London, I6I6).

Stevenson, Matthew, Observations upon Lillie's Almanack (London, I673).

Strangehopes, Samuel, A book of knowledge in three parts (London, I664).

Swan, John, Speculum mundi, or, A glasse representing the face of the world (London, I643).

Tanner, John, The Hidden Treasures of the Art of Physick (London, I659).

Taylor, John, A Discovery by Sea, From London to Salisbury (London, I630).

Toll, Thomas, A Female Duel, or The Ladies [sic] Looking-glass (London, I66I).

Trigge, Thomas, The fiery trignon revived (London, 1672 ).

Trye, Mary, Medicatrix, or the Woman-physician (London, $\left.{ }_{1} 675\right)$.

Tryon, Thomas, Healths [sic] Grand Preservative: or, the Womens [sic] Best Doctor (London, I682).

— The Country-man's Companion, or A New Method of Ordering Horse Q Sheep (London, I688).

- The Way to Health, Long Life and Happiness: or, A Discourse of Temperance (London, I697).

Turner, Robert, The Compleat Bone-setter (London, 1656 ).

Turner, W., A new boke of the natures and properties of all wines that are commonly used here in England (London, C.I568).

Turner, William, A Compleat History of the Most Remarkable Providences (London, I697).

Tusser, Thomas, Five Hundred Points of Good Husbandry (London, I553).

Vaughn, William, Directions for Health, both Naturall and Artificall (London, I6I7).

V.B., A table of the 12 astrologicall houses of heaven (London, I654).

Venner, Tobias, Via recta ad vitam longam, or, A plain philosophicall demonstration (London, I638).

W.W., Health's new store-house opened (London, I66r).

Webster, John, Academiarum Examen (London, I654).

Westwood, Anthony, De Variolis \& Morbilis: of the Small Pox and Measles (London, I656).

Whalley, John, Directions for the use of Whalley's Pills and Elixir (Dublin, c.I7Io).

Wharton, George, Bellum Hybernicale or Ireland's Warre Astrologically Demonstrated (London, I647).

Whitaker, Tobias, An elenchus of opinions concerning the cure of the small pox (London, I66I).

- The Tree of Humane Life, or, The Bloud of the Grape (London, I638).

Willis, Thomas, The London Practice of Physick (London, I685).

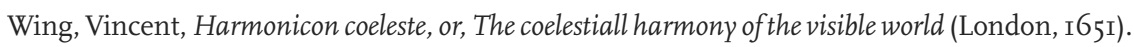

- Astronomia instaurata, or, A new compendious restauration of astronomie (London, ${ }_{1656} 6$ ).

_- Examen Astronomiae Carolinae, or a short Mathematicall Discourse (London, I665). 


\section{Additional select bibliography}

Winter, Salvator, Directions for the use of my Elixir (London, I664).

Wood, Anthony, Wood's Life and Times: The Life and Times of Anthony Wood, Antiquary of Oxford 1632-1695, ed. Andrew Clark (Oxford, I891).

Woodward, Daniel, Amicus Naturae, An Advertisement of the Virtues of Woodward's Cordiall Pills, and Elixir Salutis (London, c.I690).

Wooley, Hannah, The Gentlewomans [sic] Companion (London, I675).

Worlidge, John, Systema Horti-culturae: or, the Art of Gardening in Three Books (London, I677).

\section{SECONDARY SOURCES}

Abbott, Mary, Life Cycles in England 1560-1720: Cradle to Grave (London, I996).

Ackerknecht, Erwin, A Short History of Medicine (New York, I955).

—, 'The end of Greek diet [sic]', Bulletin of the History of Medicine, 45 (I97I), 242-249.

Addy, John, Sin and Society in the Seventeenth Century (London, I989).

Ainsworth, G.C., Introduction to the History of Medical and Veterinary Mycology (Cambridge, UK, I986).

Albala, Ken, Eating Right in the Renaissance (Berkeley, CA, 2002).

— Food in Early Modern Europe (Westport, CT, 2003).

Alden, John, 'Pills and publishing: some notes on the English book trade, I660-I715', The Library, 2I (I952), 2I-37.

Allen, Don Cameron, Star-Crossed Renaissance: The Quarrel about Astrology and Its Influence in England (Durham, NC, I94I).

Andersen, J. and E. Sauer, 'Current trends in the history of reading' in J. Andersen and E. Sauer (eds) Books and Readers in Early Modern Britain: Material Studies (Philadelphia, 2002), pp. I-22.

Anselment, Raymond, 'Seventeenth-century pox: the medical and literary realities of venereal disease', The Seventeenth Century, 4 (1989), 189-195.

__ 'Smallpox in seventeenth century English literature: reality and the metamorphosis of wit', Medical History, 33 (I989), I-4I.

—, The Realms of Apollo: Literature and Healing in Seventeenth-Century England (London, I995).

_ - " “The Wantt [sic] of Health": an early eighteenth-century self-portrait of sickness', Literature and Medicine, I52 (1996), 225-243.

Arcangeli, Alessandro, Recreation in the Renaissance: Attitudes Towards Leisure and Pastimes in European Culture, c. 1425-1675 (Basingstoke, 2003).

Arnold, Ken, Roy Porter and Lise Wilkinson, Animal Doctor - Birds and Beasts in Medical History: An Exhibition at the Wellcome Institute for the History of Medicine (London, I994).

Arrizabalaga, J., 'Medical responses to the French Disease in Europe at the turn of the sixteenth century' in K. Siena (ed.) Sins of the Flesh: Responding to Sexual Disease in Early Modern Europe (Toronto, Canada, 2005). 
Atherton, Ian, “"The Itch Grown a Disease”: manuscript transmissions of news in the seventeenth century', in J. Raymond (ed.) News, Newspapers and Society in Early Modern Britain (London, I999), pp. 39-66.

Atkinson, C.B. and J.B. Atkinson, 'Anne Wheathill's A Handfull of Holesome (though Homelie) Hearbs (I584): the first English gentlewoman's prayer book', Sixteenth Century Journal, 27 (Autumn, 1996), 659-672.

Axtell, James L., 'Education and status in Stuart England: the London physician', History of Education Quarterly, Io (1970), I42-I59.

Baldwin, Geoff, 'The "public" as a rhetorical community in early modern England' in A. Shepard and P. Washington (eds) Communities in Early Modern England: Networks, Place, Rhetoric (Manchester, 2000), I99-216.

Baldwin, Martina R., 'Toads and plague: the amulet controversy in seventeenth century medicine', Bulletin of the History of Medicine, 67 (I993), 227-247.

Barker, Hannah, Newspapers, Politics and English Society 1695-1855 (London, 2000).

Barry, Jonathan, 'Literacy and literature in popular culture: reading and writing in historical perspective' in T. Harris (ed.) Popular Culture in England c.1500-1800 (London, I995), pp. 69-94.

Barton, Nicholas, 'Physician of Stratford. Dr. John Hall: his life, times and patients', Journal of Medical Biography, 8 (2000), 8-I5.

Barton, Tamsyn S., Power and Knowledge: Astrology, Physiognomics, and Medicine under the Roman Empire (Ann Arbor, MI, 2002).

Beier, Lucinda McCray, 'Sickness and in health: a seventeenth-century family's experience' in Roy Porter (ed.) Patients and Practitioners (Cambridge, UK, I985), pp. IOI-I28.

- Sufferers and Healers: The Experience of Illness in Seventeenth-Century England (London, I987).

Bell, F.R., 'The days of the farriers', Veterinary History, 9 (I977), 3-6.

Bellamy, David and Andrea Pfister, World Medicine: Plants, Patients and People (Oxford, I992).

Bennett, H.S., 'Caxton and his public', The Review of English Studies, I9, No. 74 (1943), II3-II9.

—, English Books and Readers 1558 to 1603 (Cambridge, UK, I965).

—, English Books and Readers 1603-1640 (Cambridge, UK, I970).

Bennett, Reginald R., Materia Medica and Pharmacy (London, I92I).

Benson, J., The Rise of Consumer Society in Britain, 1880-1980 (Aldershot, 1994).

— and G. Shaw, The Evolution of Retail Systems, c. 1800-1914 (Aldershot, I992).

Berg, Maxine, 'New commodities, luxuries and their consumers in eighteenth century England' in M. Berg and H. Clifford (eds) Consumers and Luxury: Consumer Culture in Europe (Manchester, 1999), pp. 63-87.

Berger, R.M., 'The development of retail trade in provincial England, ca. I550-I700' in J. Benson and G. Shaw (eds) The Retail Trade, Vol. II (London, I999), pp. I86-29I.

Bever, Edward, 'Witchcraft fears and psychosocial factors in disease', Journal of Interdisciplinary History, 30 (2000), 573-590. 


\section{Additional select bibliography}

Birken, William, 'The dissenting tradition in English medicine in the seventeenth and eighteenth centuries', Medical History, 39 (I995), I97-2I8.

Birrell, T.A., 'Reading as pastime: the place of light literature in some gentlemen's libraries of the seventeenth century' in R. Myers and M. Harris (eds) Property of a Gentleman: The formation, organisation and dispersal of the private library 1620-1920 (Winchester, I99I), pp. II3-I32.

Black, Jeremy, The English Press 1621-1681 (Stroud, 200I).

Blagden, Cyprian, 'The distribution of almanacks in the second half of the seventeenth century', Studies in Bibliography, II (I958), I07-II6.

—, The Stationers' Company - A History, 1403-1959 (London, I960).

_ - 'Thomas Carnan and the almanack monopoly', Studies in Bibliography, I4 (I96I), 23-34.

Blair, Ann, 'Humanist methods in natural philosophy: the commonplace book', Journal of the History of Ideas, 53, No. 4 (October-December I992), 54I-55I.

Blaisdell, John D., 'Rabies in Shakespeare's England', Historia Medicinae Veterinariae, I6 (I99I), I-80.

_ ' 'The deadly bite of ancient animals written evidence for rabies', Veterinary History, New Series, 8 (London, 1994), 22-27.

Blake, John B., 'The Compleat Housewife', Bulletin of the History of Medicine, 49 (I975), $30-43$.

Blanning, T.C.W., The Culture of Power and the Power of Culture: Old Regime Europe 1660-1789 (Cambridge, UK, 2002).

Blayney, Peter W.M., The Stationers' Company before the Charter 1430-1557 (Cambridge, UK, 2003).

Bober, Harry, 'The Zodiacal Miniature of the Très Heures of the Duke of Berry: its sources and meaning', Journal of the Warburg and Courtauld Institutes, II (I948), I-34.

Borsay, Peter, 'The culture of improvement' in P. Longford (ed.) The Eighteenth Century: 1688-1815 (Oxford, 2002), pp. I83-204.

- The English Urban Renaissance: Culture and Society in the Provincial Town, 1660-1770 (Oxford, I989).

Bosanquet, Eustace F., 'Proceedings: Leonard Digges and his books', Oxford Bibliographical Society, 4 (1926), 247-253.

__ 'English seventeenth-century almanacks', The Library, Fourth Series, Io (March, I930), 36I-397.

— - 'Notes on further addenda to English printed almanacks and prognostications to I600', The Library, Fourth Series, I8 (1938), 39-66.

Bragman, A., 'Alligation alternate and the composition of medicines: arithmetic and medicine in early modern England', Medical History, 49 (2005), pp. 293-320.

Brailsford, Dennis, Sport and Society: Elizabeth to Anne (London, I969).

Brears, Peter, 'Decoration of the Tudor and Stuart table' in C. Anne Wilson (ed.) Food and Society: The Appetite and the Eye (Edinburgh, I991), pp. 56-97.

Briggs, Asa and Peter Burke, A Social History of the Media: From Gutenberg to the Internet (Cambridge, UK, I992). 
Brockbank, William, 'Sovereign remedies: a critical depreciation of the seventeenth-century London pharmacopoeia', Medical History, 8 (I964), I-I4.

Bruster, Douglas, 'The structural transformation of print in late Elizabethan England' in A.F. Marotti and M.D. Bristol (eds) Print, Manuscript and Performance: The Changing Relations of the Media in Early Modern England (Columbus, OH, 2000), pp. 49-80.

Bryson, Anna, From Courtesy to Civility: Changing Codes of Conduct in Early Modern England (Oxford, I998).

Burke, Peter, 'Popular culture in seventeenth-century London', London Journal, 3 (London, I977), I43-I62.

—, Popular Culture in Early Modern Europe, second edition (Aldershot, I994).

Burke, Victoria, 'Women and early seventeenth-century manuscript culture: four miscellanies', The Seventeenth Century, I2, No. 2 (autumn, I997), I35-I5O.

Burnby, Juanita G.L., 'Pharmaceutical advertisement in the seventeenth and eighteenth centuries', European Journal of Marketing, 22 (I988), 24-40.

—_ 'The early years of the pharmaceutical industry' in J. Richmond, J. Stevenson and A. Turton (eds) The Pharmaceutical Industry: A Guide to Historical Records (Aldershot, 2003), pp. I-I3.

Burnham, John C., 'Garrison lecture: how the concept of profession evolved in the work of historians of medicine', Bulletin of the History of Medicine, 70 (I996), I-24.

Burnett, John, Liquid Pleasures: A Social History of Drink in Modern Britain (London, 1999).

Bylebyl, J.J., 'Galen on the non-natural causes of variation in the pulse', Bulletin of the History of Medicine, 45 (I97I), 482-485.

_- 'Disputation and description in the Renaissance pulse controversy' in Andrew Wear, Roger French and M. Lonie (eds) The Medical Renaissance of the Sixteenth Century (Cambridge, UK, I995), pp. 223-245.

Bynum, W.F., 'Medicine at the English Court I688-I837' in Vivian Nutton (ed.) Medicine at the Courts of Europe 1500-1837 (London, 1989), pp. 262-89.

Camden, C., 'Elizabethan almanacs and prognostications', The Library, Fourth Series, Io (1932), 83-108.

Capp, Bernard, Astrology and the Popular Press: English Almanacs 1500-1800 (London, 1979).

__, 'Popular literature' in Barry Reay (ed.) Popular Culture in Seventeenth-Century England (London, 1985), 198-232.

- The World of John Taylor the Water-Poet (Oxford, I994).

—_, 'Separate domains? Women and authority in early modern England' in Paul Griffiths, Adam Fox and Steve Hindle (eds) The Experience of Authority in Early Modern England (Cambridge, UK, I996), pp. II7-I45.

Carey, Hilary M., Courting Disaster: Astrology at the English Court and University in the Later Middle Ages (London, I992).

Carter, Henry, A History of the Oxford University Press, Vol. I (Oxford, I975).

— , 'The history of rabies', Veterinary History, New Series, 9 (London, I996), 20-3I.

Chapman, Allan, 'Astrological medicine' in Charles Webster (ed.) Health, Medicine and Morality in the Sixteenth Century (Cambridge, UK, I979), pp. 275-300. 


\section{Additional select bibliography}

Chapman, Allan, Astronomical Instruments and their Uses (Aldershot, 1996).

— Gods in the Sky: Astronomy from the Ancients to the Renaissance (Basingstoke, 200I).

Christensen, C. Paul, 'The rise of London's book trade', in L. Hellinga and J.B. Trapp (eds) The Cambridge History of the Book in England, Vol. III (Cambridge, UK, I999), I28-I48.

Chartier, Roger, The Order of Books: Readers, Authors, and Libraries in Europe Between the Fourteenth and Eighteenth Centuries (Cambridge, UK I992).

Chartres, J.A., 'Food consumption and internal trade' in A.L. Beier and R. Finlay (eds) London 1500-1700: The Making of the Metropolis (London, I986), pp. I9I-I99.

—, Internal Trade in England 1500-1700 (London, I977).

Cipolla, Carlo M., Miasmas and Disease: Public Health and the Environment in the Pre-industrial Age, trans. E. Potter (New Haven, CT, 1992).

Clark, George, A History of the Royal College of Physicians of London, Vol. I (London, I964).

Clark, J.C.D., English Society 1660-1832: Religion, Ideology and Politics During the Ancient Regime (Cambridge, UK, 2000).

Clark, Stuart, 'Demons and disease: the disenchantment of the sick (I500-I700)' in Marijke Gijswijt-Hofstra, Hilary Marland and Hans De Wardt (eds) Illness and Healing Alternatives in Western Europe (London, 1997), pp. 38-57.

—, Thinking with Demons: The Idea of Witchcraft in Early Modern Europe (Oxford, 1997).

Cody, L.F., ' "No cure, no money" or the invisible hand of quackery', Studies in Eighteenth Century Culture, 28 (I999), I03-I30.

Cohen, E.H. and J.S. Ross, 'The commonplace book of Edmond Halley', Notes and Records of the Royal Society of London, Vol. 40, No. I (1985), pp. I-40.

Comben, Norman, 'Snape's purging pill for horses - I692', The Veterinary Record, 84 (I969), 434-435.

Company of Stationers, A Transcript of the Registers of the Worshipful Company of Stationers from 1640-1708 AD (London, I9I4).

Cook, Harold J., 'Good advice and little medicine: the professional authority of early modern English physicians', Journal of British Studies, 33 (January I994), I-3I.

—. The Decline of the Old Medical Regime in Stuart London (London, I986).

Cook, Judith, Dr. Simon Forman: A Most Notorious Physician (London, 200I).

Corbett, Margery and Ronald Lightbown, The Comely Frontispiece: The Emblematic Title-Page in England 1550-1660 (London, 1979).

Corbin, Alain, The Foul and The Fragrant: Odour and the Social Imagination (London, I986, reprint 1996 ).

Cotchin, Ernest, The Royal Veterinary College: A Bicentenary History (Buckingham, I990).

Courtwright, D.T., Forces of Habit: Drugs and the Making of the Modern World (London, 200I).

Cox, Nancy, The Complete Tradesman: a Study of Retailing, 1550-1820 (Aldershot, 2000).

Crawford, Patricia, 'Printed advertisements for women medical practitioners in London, I670-I7Io', Society for the Social History of Medicine Bulletin, 35 (I984), 66-70.

- 'Women's published writings, I600-I700' in Mary Prior (ed.) Women in English Society, 1500-1800 (London, I985), pp. 2II-282. 
—_, 'Sexual knowledge in England, I500-I750' in Roy Porter and Miklaus Teich (eds) Sexual Knowledge, Sexual Science. The History of Attitudes to Sexuality (Cambridge, UK, I994), 82-106.

Crellin, J. and J.R. Scott, 'Lionel Lockyer and his pills', Proceedings of the XXIII International Congress of the History of Medicine, 2 vols (London, I972), II82-II86.

Cressy, David, Literacy and the Social Order: Reading and Writing in Tudor and Stuart England (Cambridge, UK, I980).

—, Birth, Marriage, and Death: Ritual, Religion and the Life Cycle in Tudor and Stuart England (Oxford, I997).

Cross, Gary, A Social History of Leisure Since 1600 (State College, Pennsylvania, 1990).

Crowl, Thomas E., 'Bloodletting in veterinary medicine', Veterinary Heritage, I9 (I996), I5-2I.

Crowley, John, 'The sensibility of comfort', American Historical Review, I04, No. 3 (June I999), 749-782.

Curry, Patrick, 'Saving astrology in Restoration England: "Whig” and "Tory" Reforms' in Patrick Curry (ed.) Astrology, Science and Society (Woodbridge, Suffolk, I987), pp. $245-260$.

—, Prophecy and Power: Astrology in Early Modern England (Princeton, NJ, I989).

—_ 'Astrology in early modern England: the making of a vulgar knowledge' in Stephen Pumfrey, Paolo L. Rossi and Maurice Slawinski (eds) Science, Culture, and Popular Belief in Renaissance Europe (Manchester, I99I), pp. 274-29I.

Curth, Louise Hill, 'English almanacs and animal health care in the seventeenth century', Society and Animals, 8 (2000), 7I-86.

— - 'The care of the brute beast: animals and the seventeenth-century medical marketplace', Social History of Medicine, I5 (2002), 375-392.

- 'The commercialisation of medicine in the popular press: English almanacs I640-I700', The Seventeenth Century, I7 (Spring, 2002), 48-69.

—., 'Almanacs as medical mediators' in C. Usborne and W. de Blecourt (eds) Mediating Medicine: Cultural Approaches to Illness and Treatment in Early Modern and Modern England (Routledge, 2003), pp. 56-70.

__ 'Animals, almanacs and astrology: seventeenth century animal health care in England', Veterinary History, I2 (November 2003), 33-54.

— L Louise Hill, 'Lessons from the past: preventative medicine in early modern England', Medical Humanities, 29 (2003), I6-20.

_ , 'The medicinal value of wine in early modern England', The Social History of Alcohol and Drugs, I8 (2003), 35-50.

—_ 'Astrological medicine and the popular press in early modern England', Cosmos and Culture, 9, No. I (Spring/Summer 2005), 73-94.

- The medical content of English almanacs', Journal of the History of Medicine and Allied Sciences, 6o, No. I (July 2005), 255-282.

— - 'Introduction: perspectives on the evolution of the retailing of pharmaceuticals' in L. Hill Curth (ed.) From Physick to Pharmacology: Five Hundred Years of British Drug Retailing (Aldershot, 2006), pp. I-I2. 


\section{Additional select bibliography}

Curth, Louise Hill, 'Medical advertising in the popular press: almanacs and the growth of proprietary medicines' in L. Hill Curth (ed.) From Physick to Pharmacology: Five Hundred Years of British Drug Retailing (Aldershot, 2006), pp. 29-48.

-, 'A Remedy for his Beast: animal health care in early modern Europe', Intersections: Representations of Animals, Yearbook for Early Modern Studies, 6 (2007).

- The Care of Brute Beasts: A Social and Cultural Study of Veterinary History in Early Modern England (Leiden, 2008).

— A. Smyth (ed.) A Pleasing Sinne: Drink and Conviviality in 17th Century England (Cambridge, UK, 2004), pp. I43-I59.

Cust, Richard, 'News and politics in early seventeenth-century England' in Richard Cust and Ann Hughes (eds) The English Civil War (London, 1997), pp. 233-260.

Dannenfeldt, Karl H., 'Sleep: theory and practice in the late Renaissance', Journal of the History of Medicine and Allied Sciences, 4I (I986), 4I5-44I.

Davenport-Hines, Richard, The Pursuit of Oblivion: A Social History of Drugs (London, 2002).

Dear, Peter, Revolutionizing the Sciences: European Knowledge and Its Ambitions 1500-1700 (Basingstoke, 200I).

De Blecourt, Willem and Cornelie Usborne, 'Preface: situating "alternative medicine" in the modern period', Medical History, 43 (I999), 283-285.

Demaitre, Luke, 'The art and science of prognostication in early university medicine', Bulletin of the History of Medicine, 77, No. 4 (2003), 765-788.

Dobson, Mary J., Contours of Death and Disease in Early Modern England: The Spectrum of Death, Disease and Medical Care (Cambridge, UK, 1997).

Doherty, F., 'The anodyne necklace: a quack remedy and its promotion', Medical History, 34 (I990), 268-293.

Dreyfus, John, 'The invention of spectacles and the advent of printing', The Library, Sixth Series, Io (1988), 93-106.

Drummond, J.C. and Anne Wilbraham, The Englishman's Food: Five Centuries of English Diet (London, I958).

Duffin, Jacalyn, Lovers and Livers: Disease Concepts in History (London, 2005).

Dunlop, Robert and David Williams, Veterinary Medicine - An Illustrated History (Chicago, I996).

Dunn, Richard, Astrology in Harriot's Time, The Durham Thomas Harriot Seminar, Occasional Paper, I4 (Durham, UK, I995).

Eales, Jacqueline, Women in Early Modern England 1500-1700 (London, I998).

Earle, Peter, The Making of the English Middle Class: Business, Society and Family Life in London 1660-1730 (London, 1989).

- A City Full of People: Men and Women of London 1650-1750 (London, 1994).

Edwards, Peter, The Horse Trade of Tudor and Stuart England (Cambridge, UK, I988).

Eisenstein, Elizabeth, The Printing Press as an Agent of Change: Communications and Cultural Transformation in Early Modern Europe (Cambridge, UK, I979).

—, The Printing Revolution in Early Modern Europe (Cambridge, UK, I983). 
Eshleman, Michael K., 'Diet during pregnancy in the sixteenth and seventeenth centuries', Journal of the History of Medicine and Allied Sciences, 30 (I975), 22-39.

Evenden, Doreen, 'Gender differences in the licensing and practice of female and male surgeons in early modern England', Medical History, 42 (I998), I94-2I6.

—, The Midwives of Seventeenth-century London (Cambridge, UK, 2000).

Ezell, Margaret J.M., Social Authorship and the Advent of Print (Baltimore, MA, I999).

Febvre, Lucien and Henri-Jean Martin, The Coming of the Book: the Impact of Printing 1450-1800, trans. David Gerard (London, I976).

Fissell, Mary E., Patients, Power, and the Poor in Eighteenth-Century Bristol (Cambridge, UK, I99I).

_ - 'Readers, texts, and contexts: vernacular medical works in early modern England' in Roy Porter (ed.) The Popularization of Medicine 1650-1850 (London, I992).

Fletcher, Anthony, Gender, Sex and Subordination in England 1500-1800 (New Haven CT, I995).

Fontaine, Laurence, History of Pedlars in Europe (Durham, NC, I996).

Ford, Wyn, 'The problems of literacy in early modern England', History, 78 (I993), 22-37.

Fox, Adam, 'Custom, memory and the authority of writing' in Paul Griffiths, Adam Fox and Steve Hindle (eds) The Experience of Authority in Early Modern England (New York, I996), pp. 89-II6.

—, Oral and Literate Culture in England 1500-1700 (Oxford, 2000).

French, Roger, 'Astrology in medical practice' in L. Garcia-Ballester, R. French, J. Arrizablaga and A. Cunningham (eds) Practical Medicine from Salerno to the Black Death (Cambridge, UK, I999), pp. 30-59.

—, 'Foretelling the future: Arabic astrology and English medicine in the late twelfth century', ISIS, 87 (September I996), 453-480.

—, Medicine Before Science: The Business of Medicine from the Middle Ages to the Enlightenment (Cambridge, UK, 2003).

Friedman, Jerome, Miracles and the Pulp Press During the English Revolution: The Battle of the Frogs and Fairford's Flies (London, I993).

Furdell, Elizabeth Lane, 'Grub Street commerce: advertisements and politics in the early modern press', The Historian, 63 (2000), 35-52.

—, The Royal Doctors 1485-1714: Medical Personnel at the Tudor and Stuart Courts (Rochester, NY, 200I).

—, Publishing and Medicine in Early Modern England (Rochester, NY, 2002).

Garin, Eugenio, Astrology in the Renaissance - The Zodiac of Life, trans. Carolyn Jackson and June Allen (London, I983).

Gauquelin, Michel, Astrology and Science (London, I969).

Geneva, Ann, Astrology and the Seventeenth Century Mind: William Lilly and the Language of the Stars (Manchester, I995).

Genuth, Sara Schechner, Comets, Popular Culture, and the Birth of Modern Cosmology (Princeton, NJ, I997).

Gentilcore, David, 'Was there a "popular medicine” in early modern Europe?', Folklore, II5 (2004), I5I-I66. 


\section{Additional select bibliography}

Gibson, Jonathan, 'Significant space in manuscript letters', The Seventeenth Century, I2 (I997), I-I2.

Gibson, Rev. T. Ellison (ed.), A Cavalier's Note Book (London, I880).

Gil-Sotres, Pedro, 'The regimens of health', in M.D. Grmek (ed.) Western Medical Thought From Antiquity to the Middle Ages (Cambridge, MA, I998), pp. 29I-3I8.

Gowing, Laura, Common Bodies: Women, Touch and Power in Seventeenth-Century England (New Haven, CT, 2003).

Grafton, Anthony, 'Starry messengers: recent work in the history of Western astrology', Perspectives on Science, 8, No. I (2000), 70-83.

- Cardano's Cosmos: The Worlds and Works of a Renaissance Astrologer (Cambridge, MA, I999)

Grant, Mark, Galen on Food and Diet (London, 2000).

Green, Ian, Print and Protestantism in Early Modern England (Oxford, 2000).

Green, Monica H., 'From "Diseases of Women" to "Secrets of Women”: the transformation of gynaecological literature in the later Middle Ages', Journal of Medieval and Early Modern Studies, 30 (2000), 5-39.

Guthrie, Douglas, A History of Medicine (London, I960).

Guy, William, The Age of Agony (Chicago, 1986).

Halasz, Alexandra, 'Pamphlet surplus: John Taylor and subscription publication' in A.F. Marotti and M.D. Bristol (eds) Print, Manuscript and Performance: the Changing Relations of the Media in Early Modern England (Columbus, OH, 2000).

- The Marketplace of Print: Pamphlets and the Public Sphere in Early Modern England (Cambridge, UK, I997).

Harding, Vanessa, 'Early modern London I550-I700', The London Journal, 20 (I995), 34-45.

Hargreaves, Anne, 'Some later seventeenth-century book-trade activities', Quadrat, 6 (I997), 3-6.

Harley, David, 'Rhetoric and the social construction of sickness and healing', Social History of Medicine, 3 (I999), 407-436.

Harris, Michael, 'Timely notices: the uses of advertising and its relationship to news during the late seventeenth century' in J. Raymond (ed.) News, Newspapers and Society in Early Modern Britain (London, I999), pp. I4I-I56.

Harrison, Mark, 'From medical astrology to medical astronomy: sol-lunar and planetary theories of disease in British medicine c. I700-1850', The British Journal for the History of Science, 33 (2000), 25-48.

—, Disease and the Modern World 1500 to the Present Day (Cambridge, UK, 2004).

Hartley, Dorothy, Food in England (London, 1954).

Hawkes, G., Sex and Pleasure in Western Culture (Cambridge, UK, 2004).

Hellinga, L. and J.B. Trapp (eds), The Cambridge History of the Book in Britain, Vol. III I400-I557 (Cambridge, UK, I999).

Henry, John, 'The matter of souls: medical theory and theology in seventeenth-century England' in Roger French and Andrew Wear (eds) The Medical Revolution of the Seventeenth Century (Cambridge, UK, I989), pp. 48-II2. 
Hetet, John, 'The wardens' accounts of the Stationers' Company I663-I679' in R. Myers and M. Harris (eds) Economics of the British Book Trade 1605-1939 (Cambridge, UK, I985), 32-59.

Hinds, Peter, 'Roger L'Estrange, the Rye House Plot and the regulation of political discourse in late-seventeenth century London', The Library, Seventh Series, 3, No. 2 (March 2002), 3-3I.

Hobby, Elaine, 'Vertue of Necessity': English Women's Writing 1649-88 (London, I988).

— - 'A woman's best setting out is silence: the writings of Hannah Wolley' in Gerald MacLean (ed.) Culture and Society in the Stuart Restoration: Literature, Drama, History (Cambridge, UK, I995), pp. I79-I93.

— , 'Gender, science and midwifery: Jane Sharp: The Midwives Book (IG7I)' in C. Jowitta and D. Watt (eds) The Arts of Seventeenth Century Science (Aldershot, 2002), pp. I46-I59.

Hobhouse, Edmund, 'The library of a physician circa I700', The Library, Io (London, I929), 313-326.

Hodgson, Barbara, In the Arms of Morpheus: The Tragic History of Laudanum, Morphine, and Patent Medicines (Buffalo, NY, 200I), pp. I8, 24

Holloway, S.F., 'The regulation of the supply of drugs in Britain before $1868^{\prime}$ ' in R. Porter and M. Teich (eds) Drugs and Narcotics in History (Cambridge, UK, I995), 77-96.

Holmstedt, B. and G. Liljestrand, Readings in Pharmacology (London, I963).

Horrocks, T.A., 'Rules, remedies and regimens: health advice in early American almanacs' in C. Rosenberg (ed.) Right Living: An Anglo-American Tradition of Self-Help Medicine and Hygiene (Baltimore, MA, 2003), pp. II2-I46.

Hoskin, Michael, The History of Astronomy: A Very Short Introduction (Oxford, 2003).

Houlbrooke, Ralph A., Death, Religion, and the Family in England, 1480-1750 (Oxford, 1998).

Huisman, Frank, 'Shaping the medical market: on the construction of quackery and folk medicine in Dutch historiography', Medical History, 43 (I999), 359-375.

Hunter, Lynette, Women and domestic medicine: lady experimenters, I570-1620' in Lynette Hunter and Sarah Hutton (eds) Women, Science and Medicine 1500-1700 (Thrupp, Gloucestershire, I997), pp. 89-I07.

- 'Books for daily life: household, husbandry, behaviour' in J. Barnard and D.F. McKenzie (eds) The Cambridge History of the Book, Vol. IV, I557-I695 (Cambridge, UK, 2002), pp. 514-532.

Hunter, Michael, Science and Society in Restoration England (Cambridge, UK, I98I).

Hunter, Michael, 'Science and astrology in seventeenth-century England: an unpublished polemic by John Flamsteed' in Patrick Curry (ed.) Astrology, Science and Society (Woodbridge, Suffolk, I987), pp. 26I-282.

Hunting, Penelope, A History of the Society of Apothecaries (London, I998).

Ingram, Martin, Church Courts, Sex and Marriage in England 1570-1640 (Cambridge, UK, I987).

_ - 'From Reformation to toleration: religious culture in England I540-1690' in T. Harris (ed.) Popular Culture in England c.1500-1850 (London, I995), pp. 98-I23.

Isaac, Peter, 'Charles Eliot and Spilsbury's Antiscorbutic Drops' in P. Isaac and B. McKay (eds) The Reach of Print: Making, Selling and Using Books (Winchester, I998), pp. I57-I74. 


\section{Additional select bibliography}

Isaac, Peter, 'Pills and print' in Robin Harris and Michael Myers (eds) Medicine, Mortality and the Book Trade (Folkestone, I998), 25-49.

Jackson, William (ed.), Records of the Court of the Stationers' Company (London, I957).

Jankovic, Vladimir, Reading the Skies: a Cultural History of English Weather, 1650-1820 (Manchester, 2000).

Jardine, Lisa, Worldly Goods: A New History of the Renaissance (London, I996).

Jewell, Helen M., Education in Early Modern England (Basingstoke, I998).

Johns, Adrian, The Nature of the Book: Print and Knowledge in the Making (Chicago, I998).

Johnson, Gerald D., 'The stationers versus the drapers: control of the press in the late sixteenth century', The Library, Sixth Series, Io, No. I (March I988), I-I7.

Jones, C., 'The great chain of buying: medical advertisement, the bourgeois public sphere and the origins of the French Revolution', The American Historical Review, IOI (February 1996), 13-40.

Jones, Peter Murray, 'Book ownership and the lay culture of medicine in Tudor Cambridge' in H. Marland and M. Pelling (eds) Medicine, Religion and Gender in England and the Netherlands 1450-1800 (Amsterdam, I996), pp. 49-67.

_- 'Medicine and science' in Lotte Hellinga and J.B. Trapp (eds) The Cambridge History of the Book in Britain, Vol. 3, I450-I557 (Cambridge, UK, I999), pp. 433-449.

Karasszon, Denis, A Concise History of Veterinary Medicine, trans. E. Farkas (Budapest, I988).

Kassell, Lauren, 'How to read Simon Forman's Casebooks: medicine, astrology and gender in Elizabethan London', Social History of Medicine, I2 (I999), 3-18.

— - 'The economy of magic in early modern England' in M. Pelling and S. Mandelbrote (eds) The Practice of Reform in Health, Medicine and Science 1500-2000 (Aldershot, 2005), pp. $43-57$.

Kelly, John T., Practical Astronomy during the Seventeenth Century: Almanac-Makers in America and England (London, I99I).

King, Helen, The Disease of Virgins: Green Sickness, Cholorosis and the Problems of Puberty (London, 2004).

King, John, 'The book trade under Edward VI and Mary I' in L. Hellinga and J.B. Trapp (eds) The Cambridge History of the Book, Vol. III (Cambridge, UK, I999), pp. I64-I75.

King, Steven and Alan Weaver, 'Lives in many hands: the medical landscape in Lancashire, I700-I820', Medical History, 44 (2000), I73-200.

Kington, Eugene R., Reading in Tudor England (Pittsburgh, PA, 1996).

Lane, Joan, 'The role of apprenticeship in eighteenth-century medical education in England' in W.F. Bynum and Roy Porter (eds) William Hunter and the Eighteenth Century Medical World (Cambridge, UK, I985), pp. 57-I05.

— - 'Farriers in Georgian England' in A.R. Mitchell (ed.) History of the Healing Professions, Vol. III (Cambridge, UK, I993), pp. 99-II7.

- Apprenticeship in England 1600-1914 (London, 1996).

- John Hall and His Patients. The Medical Practice of Shakespeare's Son-In-Law (Stratfordupon-Avon, I996). 
Larner, Christina, 'Healing in pre-industrial Britain' in Mike Saks (ed.) Alternative Medicine in Britain (Oxford, I992), pp. 25-34.

Leigh, R.A., 'The Stationers' Company's Records', The Library, 6 (London, I926), 348-357.

Levy, Fritz, 'The decorum of news' in J. Raymond (ed.) News, Newspapers and Society in Early Modern Britain (London, I999), pp. I2-38.

Lewis, Walter H. and Memory Elvin-Lewis, Medical Botany: Plants Affecting Man's Health (New York, 1977).

Lindemann, Mary, Medicine and Society in Early Modern Europe (Cambridge, UK, I999).

Lindenbaum, Peter, 'Authors and publishers in the late seventeenth century: New evidence on their relations', The Library, Sixth Series, 3 (I995), 250-269.

Longrigg, James, Greek Rational Medicine: Philosophy and Medicine From Alcmaeon to the Alexandrians (London, I993).

—, Greek Medicine From the Heroic to the Hellenistic Age: A Source Book (New York, 1998).

Maclean, Ian, Logic, Signs and Nature in the Renaissance: The Case of Learned Medicine (Cambridge, UK, 2002).

MacDonald, Michael, Mystical Bedlam: Madness, Anxiety and Healing in Seventeenth-Century England (Cambridge, UK, 1985).

_- 'Madness, suicide and the computer' in Roy Porter and Andrew Wear (eds) Problems and Methods in the History of Medicine (London, I987), pp. 207-229.

- 'The career of astrological medicine in England' in O.P. Grell and Andrew Cunningham (eds) Religio Medici - Medicine and Religion in Seventeenth-Century England (Aldershot, 1996), pp. 62-90.

McDowell, Paula, The Women of Grub Street: Press, Politics and Gender in the London Literary Marketplace 1678-1730 (Oxford, I998).

Macfarlane, Alan, The Family Life of Ralph Josselin: A Seventeenth-Century Clergyman: An Essay in Historical Anthropology (Cambridge, UK, I970).

McKitterick, Rosamund, 'Books and sciences before print' in R. McKitterick (ed.) Books and the Sciences in History (Cambridge, UK, 200I), I3-24.

Maehle, Andreas-Holger and Ulrich Tröhler, 'The ethical discourse on animal experimentation, 1650-I900' in Andrew Wear, Johanna Geyer-Kordesch and Roger French (eds) Doctors and Ethics: The Earlier Historical Setting of Professional Ethics (Amsterdam, I993), pp. 203-25I.

Mandelbrote, Giles, 'Workplaces and living spaces: London book trade inventories of the late seventeenth century' in R. Myers, M. Harris and G. Mandelbrote (eds) The London Book Trade: Topographies of Print in the Metropolis From the Sixteenth Century (London, 2003), pp. 2I-44.

Maple, Eric, 'The great age of quackery' in Mike Saks (ed.) Alternative Medicine in England (Oxford, I992), pp. 55-6I.

Martin, A. Lynn, Alcohol, Sex and Gender in Late Medieval and Early Modern Europe (Basingstoke, 200I).

Mendle, M. 'De facto freedom, de facto authority: press and Parliament I640-I643', The Historical Journal, 38, No. 2 (June I995), 307-322.

Mendelson, Sara Heller, The Mental World of Stuart Women (London, I987). 


\section{Additional select bibliography}

Mendelson, Sara Heller and Patricia Crawford, 'Stuart women's diaries and occasional memoirs' in Mary Prior (ed.) Women in English Society 1500-1800 (London, I99I), pp. I8I-2IO.

- Women in Early Modern England (Oxford, I998).

Mui, Hoh-Cheung and Lorna H. Mui, Shops and Shopkeeping in Eighteenth-Century England (London, 1989).

Nagy, Doreen Evenden, Popular Medicine in Seventeenth-Century England (Bowling Green, KY, I988).

Naphy, William and Andrew Spicer, The Black Death: A History of Plagues 1345-1730 (Stroud, 200I).

Newman, William R. and Anthony Grafton, 'Introduction: the problematic status of astrology and alchemy in premodern Europe' in W.R. Newman and A. Grafton (eds) Secrets of Nature: Astrology and Alchemy in Early Modern Europe (Cambridge, MA, 200I), pp. I-38.

Nicolson, Marjorie, 'English almanacs and the new astronomy', Annals of Science, 4 (I939), $\mathrm{I}-33$.

Niebyl, P.H., 'The non-naturals', British History of Medicine, 45 (Baltimore, MA, I97I), 486-92.

North, John, The Fontana History of Astronomy and Cosmology (London, I994).

Nummedal, Tara and Paula Findlen, 'Words of Nature: scientific books in the seventeenth century' in A. Hunter (ed.) Thornton and Tully's Scientific Books, Libraries and Collectors, Fourth Edition (Aldershot, 2000), pp. I64-216.

Nutton, Vivian, 'The drug trade in antiquity', Journal of the Royal Society of Medicine, 78 (I985), I38-I45.

—_ 'Beyond the Hippocratic Oath' in Andrew Wear, Johanna Geyer-Kordesch and Roger French (eds) Doctors and Ethics: The Earlier Historical Setting of Professional Ethics (Amsterdam, I993), pp. I0-37.

_- Ancient Medicine (London, 2004).

O'Boyle, Cornelius, Medieval Prognosis and Astrology: A Working Edition of the Aggregationes de Crisi et Creticis Diebus (Cambridge, UK, I99I).

Ong, W.J., Orality and Literacy: The Technologizing of the Word (London, 2002).

Palmer, Richard, In Bad Odour: Smell and Its Significance in Medicine from Antiquity to the Seventeenth Century (Cambridge, UK, I993), 6I-68.

Parker, Derek, Familiar to All: William Lilly and Astrology in the Seventeenth Century (London, I975).

—

Pattie, Thomas, 'Greek astrology' in Annabella Kitson (ed.) History and Astrology: Clio and Urania Confer (London, I989), pp. I5-25.

Pearson, David, 'The libraries of English bishops, I600-1640', The Library, Sixth Series, I4 (I992), 220-23I.

_ _ 'English centrepiece bookbindings I560-1640', The Library, Sixth Series, I6 (I994), 6-16. 
Pelling, Margaret, 'Appearance and reality: barber-surgeons, the body and disease' in A. Beier and Roger Finlay (eds) The Making of the Metropolis: London 1500-1700 (London, I986), pp. 82-I05.

- The Common Lot: Sickness, Medical Occupations and the Urban Poor in Early Modern England (London, 1998).

- , and F. White, Medical Conflicts in Early Modern London: Patronage, Physicians and Irregular Practitioners 1550-1640 (Oxford, 2003).

Pennell, Sara, 'Consumption and consumerism in early modern England', The Historical Journal, 42, No. 2 (I999), 549-564.

Perkins, Wendy, Midwifery and Medicine in Early Modern France: Louise Bourgeois (Exeter, I996).

Pollard, G., 'The Company of Stationers before I557', The Library, Fourth Series, I8 (I938), p. 20.

Porter, Dorothy and Roy Porter, Patient's Progress: Doctors and Doctoring in Eighteenth-Century England (Oxford, I989).

Porter, Roy, 'I think ye both quacks': the controversy between Dr Theodore Myersbach and Dr John Coakley Lettsom' in W.F. Bynum and Roy Porter (eds) Medical Fringe and Medical Orthodoxy 1750-1850 (Beckenham, Kent, I987), pp. 56-78.

—, Health for Sale: Quackery in England 1660-1850 (Manchester, I989).

- 'The patient in England, c.I660-c.I800' in Andrew Wear (ed.) Medicine in Society: Historical Essays (Cambridge, UK, I992), pp. 9I-II8.

—, 'Man, animals and medicine at the time of the founding of the Royal Veterinary College' in A.R. Mitchell (ed.) History of the Healing Professions, Vol. III (London, I993), I9-30.

- The Greatest Benefit to Mankind: A Medical History of Humanity from Antiquity to the Present (London, I997).

— and Dorothy Porter, In Sickness and In Health: The British Experience 1650-1850 (London, I988).

— Corbyn', Medical History, 33 (1989), 277-295.

Porter, Stephen, The Great Fire of London (Stroud, I996).

Prince, Leslie B., The Farrier and His Craft. The History of the Worshipful Company of Farriers (London, I980).

Pugh, Leslie P., From Farriery to Veterinary Medicine 1785-1795 (Cambridge, UK, I962).

— - 'From farriery to veterinary medicine', Veterinary History, 4 (I974-75), IO-I6.

Raach, John H., A Directory of English Country Physicians (London, I962).

Raven, James, 'The book trades' in I. Rivers (ed.) Books and Their Readers in EighteenthCentury England: New Essays (London, 200I), pp. I-34.

Raven, J., H. Small and N. Tadmor, 'Introduction: the practice and representation of reading in England' in J. Raven, H. Small and N. Tadmor (eds) The Practice and Representation of Reading in England (Cambridge, UK, I999), p. 5.

Rawcliffe, Carole, Medicine and Society in Later Medieval England (Stroud, I995). 
Raymond, Joad, Making the News: An Anthology of the Newsbooks of Revolutionary England 1641-1660 (Moreton-in-Marsh, 1993).

—, Pamphlets and Pamphleteering in Early Modern Britain (Cambridge, UK, 2003).

_ - 'The newspaper, public opinion and the public sphere in the seventeenth century' in J. Raymond (ed.) News, Newspapers and Society in Early Modern Britain (London, 1999), pp. IO9-I4I.

Reay, Barry, Popular Cultures in England 1550-1750 (London, I998).

Rogers, Pat, Grub Street: Studies in a Subculture (London, I972).

Rolls, R., 'Bark, blisters and the bath: some problems of pain relief in former times', Journal of the Royal Society of Medicine, 75 (October I982), pp. 8I2-8ig.

Roos, Anna Marie, 'Luminaries in medicine: Richard Mead, James Gibbs, and solar and lunar effects on the human body in early modern England', Bulletin of the History of Medicine, 74 (2000), 433-457.

Ruckebusch, Y., 'A historical profile of veterinary pharmacology and therapeutics', Historia Medicinae Veterinariae, 20 (1995), 49-80.

Rusche, Harry, 'Merlini Anglici: astrology and propaganda from I644 to I65I', English Historical Review, 80 (1965), 322-333.

Salisbury, Joyce E., The Beast Within: Animals in the Middle Ages (London, I994).

Schalick, W.O., 'To market, to market: the theory and practice of opiates in the Middle Ages' in M.L. Meldrum (ed.) Opiods and Pain Relief: A Historical Perspective (Seattle, 2003), pp. $5^{-20}$.

Schwabe, Calvin W., Veterinary Medicine and Human Health (Baltimore, MA, I984).

Scully, Terence, 'The sickdish in early French recipe collections' in S. Campbell, B. Hall and D. Klausner (eds) Health, Disease and Healing in Medieval Culture (Toronto, Canada, I992), pp. I32-I40.

Sharpe, Kevin, Criticism and Compliment: The Politics of Literature in the England of Charles I (Cambridge, UK, 1987).

—, Reading Revolutions: The Politics of Reading in Early Modern England (New Haven, CT, 2000).

Siena, Kevin P., Venereal Disease, Hospitals and the Urban Poor: London's 'Foul Wards', 1600-1800 (Rochester, NY, 2004).

Simon, Andre, History of the Wine Trade in England, Vol. III (London, I909).

Simons, R.C., 'ABC's, almanacs, ballads, chapbooks, popular piety and textbooks' in J. Barnard and D.F. McKenzie (eds) The Cambridge History of the Book in Britain, Vol. IV (Cambridge, UK, 2002).

Siraisi, Nancy G., 'Some current trends in the study of Renaissance medicine', Renaissance Quarterly, 37 (1984), 585-600.

— , 'The Fielding H. Garrison lecture: medicine and the Renaissance world of learning', Bulletin of the History of Medicine, I8, No. I (2004), I-36.

Slack, Paul, 'Mirrors of health and treasures of poor men: the uses of the vernacular medical literature of Tudor England' in Charles Webster (ed.) Health, Medicine and Mortality in the Sixteenth Century (Cambridge, UK, I979), pp. 237-274.

—, The Impact of Plague in Tudor and Stuart England (London, I985). 
- Poverty and Policy in Tudor and Stuart England (London, I988).

Sloan, A.W., English Medicine in the Seventeenth Century (Durham, UK, I996).

Smith, Ginnie, 'Prescribing the rules of health: self-help and advice in the late eighteenth century' in Roy Porter (ed.) Patients and Practitioners: Lay Perceptions of Medicine in Preindustrial Society (Cambridge, UK, I985), pp. 249-282.

Smith, Sir Frederick, The Early History of Veterinary Literature and Its British Development, Vol. I (London, I9I9; reprinted I976).

- The Early History of Veterinary Literature, Vol. II (London, I924).

Smithcors, F.J., Evolution of the Veterinary Art: A Narrative Account to 1850 (London, I958).

- The American Veterinary Profession (Ames, IA, I963).

—. 'Some early veterinary therapies', Veterinary Heritage, I8 (I995), 48-52.

Smoller, Lauren, History, Prophecy and the Stars: The Christian Astrology of Pierre D'Alilly 1350-1420 (Princeton, NJ, 1994).

Snodgrass, Mary Ellen, Signs of the Zodiac: A Reference Guide to Historical, Mythological, and Cultural Associations (London, I997).

Sommerville, C. John, The News Revolution in England: Cultural Dynamics of Daily Information (Oxford, I996).

Spufford, Margaret, Contrasting Communities: English Villagers in the Sixteenth and Seventeenth Centuries (Cambridge, UK, I974).

- Small Books and Pleasant Histories: Popular Fiction and Its Readership in SeventeenthCentury England (Cambridge, UK, I98I).

Stone, Lawrence, 'Literacy and education in England I640-1900', Past and Present, 42 (1969), 69-139.

- The Family, Sex and Marriage in England 1500-1800 (Cambridge, UK, I979).

Sutherland, James, The Restoration Newspaper and Its Development in Early Modern England (Cambridge, UK, I986).

Swabe, Joanna, 'The Burden of Beasts': A Historical Sociological Study of Changing Human-Animal Relations and the Rise of the Veterinary Regime (Amsterdam, 1997).

Tebeaux, Elizabeth, 'Women and technical writing, I475-I700: technology, literacy, and development of a genre' in Lynette Hunter and Sarah Hutton (eds) Women, Science and Medicine 1500-1700 (Thrupp, Gloucestershire, 1997), pp. 29-62.

Tester, S.J., A History of Western Astrology (Woodbridge, Suffolk, I987).

Thagard, Paul R., 'Why astrology is a pseudoscience', The Philosophy of Science Association, I (I978), 223-234.

Thomas, Keith, Man and the Natural World: Changing Attitudes in England 1500-1800 (London, I983).

—, Religion and the Decline of Magic (London, I97I; reprinted I99I).

Thompson, C.J.S., The Quacks of Old London (London, 1928).

Thorndike, Lynn, 'Medieval magic and science in the seventeenth century', Speculum, 28 (I953), 692-704.

— , 'The true place of astrology in the history of science', ISIS, 46 (Cambridge, UK, I955), $273-278$. 


\section{Additional select bibliography}

Thornton, Alice, Her Own Life: Autobiographical Writings by Seventeenth-Century Englishwomen (London, I998).

Tinniswood, A., By Permission of Heaven: The Story of the Great Fire of London (London, 2003).

Tobyn, Graeme, Culpeper's Medicine: A Practice of Western Holistic Medicine (Shaftesbury, Dorset, I997).

Toussaint-Samat, Maguelonne, History of Food, trans. Anthea Bell (New York, I992).

Treadwell, Michael, 'London trade publishers I675-I750', The Library, 4 (I982), 99-I34.

Voss, P., 'Books for sale: advertising and patronage in Elizabethan England', Sixteenth Century Journal, 29 (I998), pp. 733-757.

W.S., 'Early almanacs', Notes and Queries, II (I858), I34-I35.

Wall, C. and H.C. Cameron, A History of the Worshipful Society of Apothecaries of London, Vol. I, I6I7-I8I5 (London, I963).

Wall, W., 'Renaissance national husbandry: Gervase Markham and the publication of England', Sixteenth Century Journal, I7, No. 3 (Autumn I996), 767-785.

Walsham, Alexandra, Providence in Early Modern England (Oxford, 1999).

Watt, Tessa, Cheap Print and Popular Piety, 1550-1640 (Cambridge, UK, I996).

Watts, Sheldon, Disease and Medicine in World History (London, 2003).

Wear, Andrew, 'Interfaces: perceptions of health and illness in early modern England' in Roy Porter and Andrew Wear (eds) Problems and Methods in the History of Medicine (London, I988), pp. 230-256.

— - 'Medical practice in late seventeenth- and early eighteenth-century England: continuity and union' in Roger French and Andrew Wear (eds) The Medical Revolution of the Seventeenth Century (Cambridge, UK, I989), pp. 294-320.

_ - 'Making sense of health and the environment in early modern England' in Andrew Wear (ed.) Medicine in Society: Historical Essays (Cambridge, UK, I992), pp. I20-I43.

—, 'The popularisation of medicine $1650-1850$ ' in Roy Porter (ed.) The Popularization of Medicine 1650-1850 (London, I992), pp. I7-34.

— ' 'Medicine in early modern Europe, I500-I700' in L. Conrad, M. Neve, V. Nutton, R. Porter and A. Wear, The Western Medical Tradition 800 BC to AD 1800 (Cambridge, UK, I995), pp. 215-340.

_ - 'The early modern debate about foreign drugs: localism versus universalism in medicine', The Lancet, 354 (1999), I49-I5I.

Weatherill, Lorna, Consumer Behaviour and Material Culture in Britain 1660-1760 (London, I988).

_ - 'The meaning of consumer behaviour in late seventeenth and early eighteenth-century England' in Roy Porter and John Brewer (eds) Consumption and the World of Goods (London, I993), pp. 206-2I7.

Weber, Harold, Paper Bullets: Print and Kingship under Charles II (Lexington, KY, I996).

Webster, Charles, The Great Instauration: Science, Medicine and Reform 1626-1660 (New York, I976).

Wheale, Nigel, Writing and Society: Literacy, Print and Politics in Britain 1590-1660 (London, I999). 
Wiesner, Merry E., Women and Gender in Early Modern England (Cambridge, I998).

Wilkins, John, 'The contribution of Galen, De Subtilliante Diaeta (on the thinning diet)' in V. Nutton (ed.) The Unknown Galen (London, 2002), pp. 47-55.

Wilkinson, Lise, Animals and Disease: An Introduction to the History of Comparative Medicine (Cambridge, UK, I992).

Williams, Guy, The Age of Agony: The Art of Healing 1700-1800 (Chicago, 1975).

Williams, William, The Principles and Practice of Veterinary Medicine (London, I882).

Wilson, Adrian, 'The politics of medical improvement in early Hanoverian London' in Andrew Cunningham and Roger French (eds) The Medical Enlightenment of the Eighteenth Century (Cambridge, UK, I990), pp. 4-40.

Wilson, C., Anne, Food and Drink in Britain: From Stone Age to Recent Times (London, 1976).

— - 'The evolution of the banquet course: some medicinal, culinary and social aspects' in C. Anne Wilson (ed.) Food and Society: 'Banquetting Stuffe' (Edinburgh, I99I), pp. 9-35.

—, Ideal Meals and their Menus from the Middle Ages to the Georgian Era (Edinburgh, I99I).

Wilson, R., Astronomy Through the Ages: the Story of the Human Attempt to Understand the Universe (London, 1997).

Wing, Donald, Short Title Catalogue of Books Printed in England ... and of English Books . . 1641-1700, 2nd edn., 3 vols (New York, I994).

Wright, Peter, 'Astrology and science in seventeenth-century England', Social Studies of Science, 5 (London, I975), 400-42I.

Wrightson, Keith, Earthly Necessities: Economic Lives in Early Modern Britain 1450-1750 (London, 2002).

Zolar, The History of Astrology (London, 1972). 